\author{
(online) $=$ ISSN $2285-3642$ \\ ISSN-L = 2285 - 3642 \\ Journal of Economic Development, Environment and People \\ Volume 6, Issue 4, 2017 \\ URL: http://jedep.spiruharet.ro \\ e-mail: office jedep@spiruharet.ro
}

\title{
European Trade - Where is Going? Retail Entertainment
}

\author{
Jelev Viorica \\ University "Spiru Haret", Economical Science Faculty
}

\begin{abstract}
As competition grows, brand manager imagination needs to work, and sales growth solutions need to focus on customer focus attention. It is a difficult task if all brands offer discounts in the malls they are in, and the announcement of differentiation is put to the attention of specialists who offer solutions for fun of any kind for the clients. The article aims to present the evolution of world trade in recent years and the various ways of diversion invented by retailers to keep customers in store chains longer for them to buy more. I will also present the off-line consumer profile, as found in the specialty studies and the adaptation of the entertainment methods according to these shoper typologies.

The aricolul presents an example of entertainment in a mall in Bucharest, meant to boost shopping during the winter holidays. In the example presented in the article, the events scheduled at the mall during the winter holidays bring sales increases and $80 \%$ over the previous month. Concerts, doll or clown shows, fashion parades, raffles, or even automotive contests all turn commercial centers into real-life halls.

The conclusion of this article will focus on what the link between entertaiment and retail is, the new concept of RETAILTAIMENT that leads to increased sales and profits of economic agents. Running by clients has made more and more mall managers manage to adopt marketing strategies that soon turned shopping centers into real halls that lead to spectacular sales growth, especially during holidays.
\end{abstract}

Keywords: commerce, omnishopperi, entertainment, sales, omnichannel, retailtainment

JEL Codes: F10, M30

\section{Introduction}

\subsection{What does the article cover?}

The current article speaks about international trade evolution in recent years, but also about new ways to sell products in major stores according to buyers 'typology, most of which appeal to shoppers' entertainment through numerous online and offline methods.

\subsection{Why the studied problem is important?}

Finding innovative methods of retaining as much time as possible in the visitor's sales area, to be converted into buyers, leads to increased sales and business profits.

\subsection{How does the author intend to answer this question?}




\author{
(online) $=$ ISSN $2285-3642$ \\ ISSN-L = $2285-3642$ \\ Journal of Economic Development, Environment and People \\ Volume 6, Issue 4, 2017 \\ URL: http://jedep.spiruharet.ro \\ e-mail: office jedep@spiruharet.ro
}

The article has three subchapters in which we have shown the evolution of world trade in recent years, according to Eurostat data, the results of a study on the orientation of the Romanian shoppers in shopping, as well as the typology of consumers willing to buy, otherwise than in the classic way, methods and means to keep them as long as possible in stores.

\title{
1.4. What is the relationship between the article and the already existing specialized literature?
}

Because entertainment has long been a marketing method for increasing sales in large chain stores, the subject has not been much debated in the literature. Innovative methods discovered by brand managers around the world to keep shoppers as long as possible in stores will be described in future specialist sales books.

\section{Literature review}

In order to develop this topic, I have used the information received at the specialized conferences which I have attended in recent years, such as the Retail Arena, an annual conference dedicated to the large retail chains, online stores and service providers, logistics specialists and marketing, business owners and manufacturers in the FMCG industry, as well as the Biz conferences, destined for marketing, entrepreneurship, social media. I used also information from the specialized courses I wrote for Merchandising and International Marketing classes, as well as the book by Prof. Gh. Pistol, Internal TradeCourse Notes. We also used statistical information and data made available to researchers by the European Statistics Office, Eurostat, on the evolution of international trade.

\subsection{World Trade Where?}

I learned from school what trade means. According to the definition, it means supplying goods in exchange for means of payment, usually money, or other commodities, the price of which is determined by the market relationship between "demand" and "offer" [3]. As we know, trade is limited to buying, transporting and selling goods.

Commerce needs to always adapt to new sales techniques to meet new and ongoing customer requirements. Once the consumer is exposed daily to numerous offerings that invade his space and mind by all means sensed by the senses, he becomes increasingly demanding. The sight, the hearing, the smell, the touch and the taste are continually tested since we climb up to sleep on the things that surround us.

In this new world of aggressive commercials, shopping becomes more and more pretentious by the education it acquires not only in school, but also by online and offline media.

Under these circumstances, brand managers need to find new and new ways to increase sales at sales points, by conducting numerous studies to find new types of shops and their inclinations towards consumption.

According to the International Commodity Trade study, developed by the EU Statistical Office, Eurostat, the European trade of the 28 Member States carries about 15\% of world commodity trade. The value of international trade in goods is significantly higher than that of services (approximately three times), reflecting the nature of certain services that are an obstacle to cross-border trade. China and the United States were the three largest players in international trade since 2004 when China overwhelmed Japan. [5] 


\author{
(online) $=$ ISSN $2285-3642$ \\ ISSN-L = $2285-3642$ \\ Journal of Economic Development, Environment and People \\ Volume 6, Issue 4, 2017
}

URL: http://jedep.spiruharet.ro

e-mail: office jedep@spiruharet.ro

EU-28 international commodity trade with the rest of the world (sum of exports and extra-EU imports) was estimated at EUR 3517 billion in 2015 (Table 1 and Figure 1). Both imports and exports increased compared to 2014, but this increase was higher for exports ( $€ 88$ billion) than for imports ( $€ 35$ billion). Therefore, the EU-28 trade surplus has increased from $€ 11$ billion in 2014 to $€ 64$ billion in 2015.

Table 1: International trade, 2014-15

\begin{tabular}{|c|c|c|c|c|c|c|c|c|}
\hline & \multicolumn{3}{|c|}{ Exports } & \multicolumn{3}{|c|}{ Imports } & \multicolumn{2}{|c|}{ Trade balance } \\
\hline & 2014 & 2015 & $\begin{array}{l}2014-15 \\
\text { growth rate }\end{array}$ & 2014 & 2015 & $\begin{array}{c}2014-15 \\
\text { growth rate }\end{array}$ & 2014 & 2015 \\
\hline & \multicolumn{2}{|c|}{ (billion EUR) } & $(\%)$ & \multicolumn{2}{|c|}{ (billion EUR) } & (\%) & \multicolumn{2}{|c|}{ (billion EUR) } \\
\hline EU-28 (') & 1703.0 & 1790.7 & 5.1 & 1691.9 & 1726.5 & 2.0 & 11.1 & 64.2 \\
\hline Belgium & 355.5 & 359.6 & 1.1 & 342.2 & 338.8 & -1.0 & 13.3 & 20.8 \\
\hline Bulgaria & 22.0 & 23.2 & 5.1 & 26.1 & 26.4 & 1.1 & -4.1 & -3.2 \\
\hline Czech Republic & 131.8 & 142.8 & 8.4 & 116.2 & 126.8 & 9.1 & 15.6 & 16.0 \\
\hline Denmark & 83.5 & 85.9 & 2.9 & 74.8 & 77.0 & 2.9 & 8.7 & 8.9 \\
\hline Germany & 1125.0 & 1198.3 & 6.5 & 908.6 & 946.5 & 4.2 & 216.5 & 251.9 \\
\hline Estonia & 12.1 & 11.6 & -3.8 & 13.8 & 13.1 & -5.1 & -1.7 & -1.4 \\
\hline Ireland & 91.8 & 110.5 & 20.4 & 60.7 & 66.5 & 9.6 & 31.1 & 43.9 \\
\hline Greece & 27.2 & 25.8 & -5.2 & 48.0 & 43.6 & -9.1 & -20.8 & -17.8 \\
\hline Spain & 244.3 & 255.4 & 4.6 & 270.2 & 281.3 & 4.1 & -25.9 & -25.9 \\
\hline France & 436.9 & 456.0 & 4.4 & 509.3 & 515.9 & 1.3 & -72.4 & -59.9 \\
\hline Croatia & 10.4 & 11.7 & 11.9 & 17.2 & 18.6 & 8.2 & -6.7 & -6.9 \\
\hline Italy & 398.9 & 413.9 & 3.8 & 356.9 & 368.7 & 3.3 & 41.9 & 45.2 \\
\hline Cyprus & 1.4 & 1.6 & 20.9 & 5.1 & 5.0 & -1.4 & -3.7 & -3.4 \\
\hline Latvia & 11.0 & 10.9 & -0.8 & 13.3 & 12.9 & -2.9 & -2.3 & -2.0 \\
\hline Lithuania & 24.4 & 23.0 & -5.7 & 25.9 & 25.4 & -1.9 & -1.5 & -2.4 \\
\hline Luxembourg & 14.5 & 15.6 & 7.4 & 20.1 & 20.9 & 3.9 & -5.6 & -5.3 \\
\hline Hungary & 83.3 & 88.9 & 6.8 & 79.0 & 83.5 & 5.7 & 4.3 & 5.4 \\
\hline Malta & 2.2 & 2.3 & 5.4 & 5.1 & 5.2 & 1.7 & -2.9 & -2.9 \\
\hline Netherlands & 506.3 & 511.3 & 1.0 & 443.7 & 456.4 & 2.9 & 62.7 & 55.0 \\
\hline Austria & 134.2 & 137.8 & 2.7 & 137.0 & 140.1 & 2.3 & -2.8 & -2.4 \\
\hline Poland & 165.7 & 178.7 & 7.8 & 168.4 & 175.0 & 3.9 & -2.7 & 3.7 \\
\hline Portugal & 48.1 & 49.9 & 3.6 & 59.0 & 60.2 & 2.0 & -10.9 & -10.3 \\
\hline Romania & 52.5 & 54.6 & 4.0 & 58.6 & 63.0 & 7.6 & -6.1 & -8.4 \\
\hline Slovenia & 27.1 & 28.8 & 6.4 & 25.6 & 26.8 & 4.8 & 1.5 & 2.0 \\
\hline Slovakia & 65.1 & 68.0 & 4.5 & 61.7 & 66.3 & 7.5 & 3.4 & 1.7 \\
\hline Finland & 56.0 & 53.9 & -3.7 & 57.8 & 54.3 & -6.1 & -1.8 & -0.4 \\
\hline Sweden & 123.9 & 126.3 & 2.0 & 122.1 & 124.5 & 1.9 & 1.8 & 1.9 \\
\hline United Kingdom & 380.3 & 414.8 & 9.1 & 519.7 & 564.2 & 8.6 & -139.5 & -149.4 \\
\hline Iceland & 3.8 & 4.3 & 12.1 & 4.0 & 4.6 & 14.4 & -0.2 & -0.4 \\
\hline Norway & 107.5 & - & - & 67.2 & - & - & 40.3 & - \\
\hline Switzerland ( $\left.{ }^{2}\right)$ & 234.8 & 261.6 & 11.4 & 207.6 & 225.9 & 8.8 & 27.2 & 35.7 \\
\hline
\end{tabular}

(') External trade flows with extra EU-28

(2) Including Liechtenstein.

Source: Eurostat (online data codes: ext_It_intertrd, ext_It_intercc and ext_It_introle)

Source: http://ec.europa.eu/eurostat/statisticsexplained/index.php/International_trade_in_goods/ro

Following a dramatic decline in both exports and imports in 2009, the EU-28 has increased its exports to $58.7 \%$ over the next four years to reach a record high of 1,737 billion in 2013. Exports then declined to $1.9 \%$ in 2014 before rising to 5.1\% to reach a new peak in 2015 of EUR 1791 billion. Instead, the increase in imports after 2009 was 45.5\% over three years to reach a peak in 2012 of EUR 1798 billion. Although imports declined to $6.2 \%$ in 2013 before stabilizing (to $0.3 \%$ ) in 2014 and increasing by $2.0 \%$ in 2015 , it is still below the 2012 level. Germany was, by far, the largest Member State in terms of trade outside the EU28 in 2015, contributing $28.2 \%$ of EU-28 exports of goods to third countries and making almost a fifth (18.8\%) of EU-28 imports (see Figure 7). The following three largest exporters, the United Kingdom (12.9\%), France $(10.5 \%)$ and Italy (10.4\%) remained the same as in 2014 (although France's exports outside the EUhave exceeded those of Italy), these being the only EU Member States with a two-digit share of EU-28 


\author{
(online) $=$ ISSN $2285-3642$ \\ ISSN-L = $2285-3642$ \\ Journal of Economic Development, Environment and People \\ Volume 6, Issue 4, 2017 \\ URL: http://jedep.spiruharet.ro \\ e-mail: office jedep@spiruharet.ro
}

exports. The United Kingdom (15.2\%), the Netherlands (14.4\%), France (9.5\%) and Italy (8.9\%) were immediately behind Germany as regards the volume of imports of goods from third countries in 2015.

100 2000

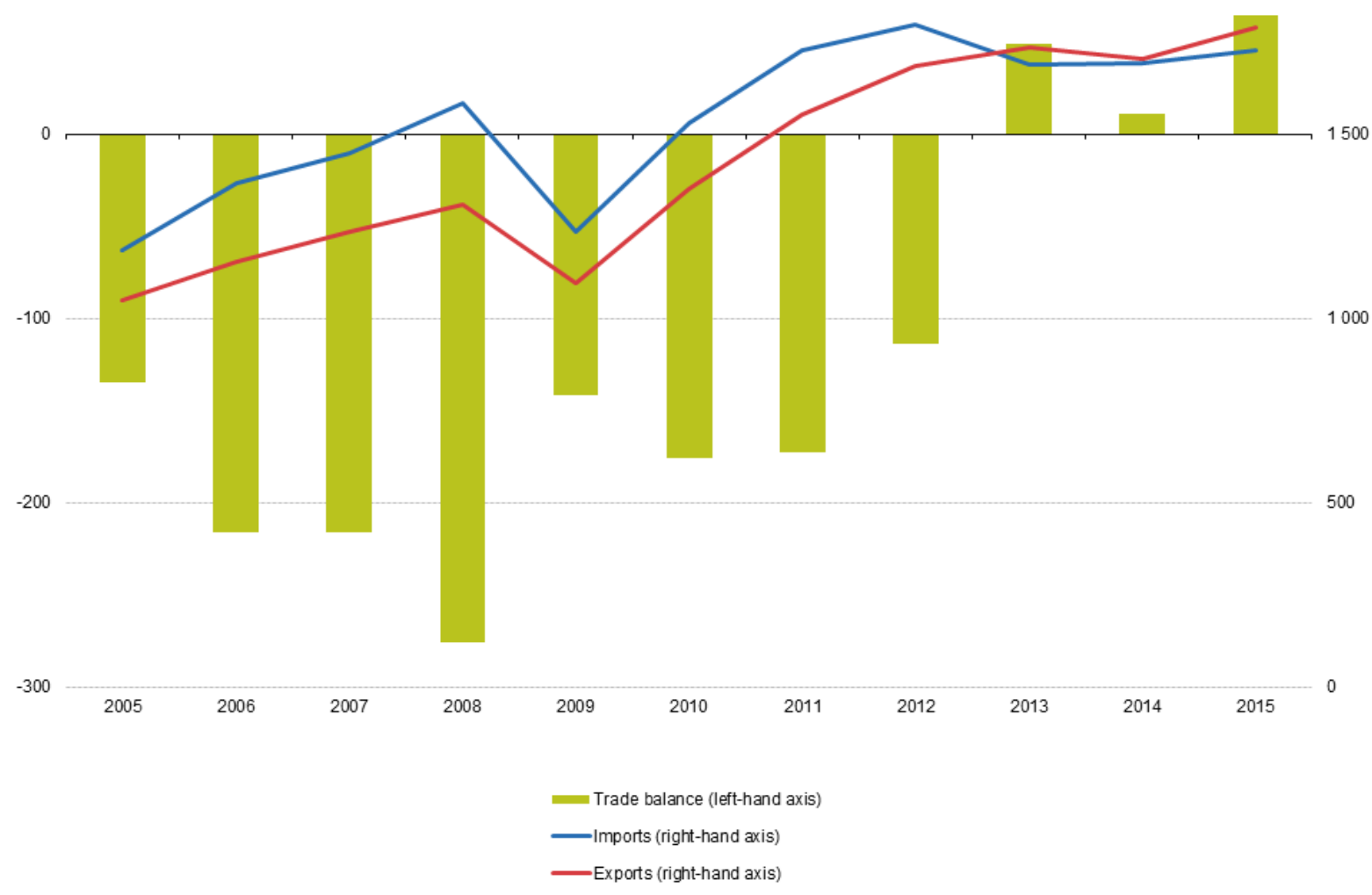

(') External trade flows with extra EU-28.

Source: Eurostat (online data code: ext_It_intertrd)

Fig. 1 Evolution of International Trade 2005-2015

Source: http: //ec.europa.eu/eurostat/statisticsexplained/index.php/International_trade_in_goods/ro

The relatively high percentage for the Netherlands can, at least in part, be explained by the considerable volume of goods entering the EU via Rotterdam, which is the EU's largest maritime port. The largest surplus of extra-EU-28 commodity trade, estimated at EUR 179.4 billion in 2015, was recorded by Germany, followed by Italy (EUR 33.7 billion) and Ireland (EUR 29.3 billion) .

The main groups of products that are the subject of international trade are represented in Figure 2. [5]

Between 2010 and 2015, the value of EU-28 imports and exports increased for all the product groups shown in Figure 2, excluding imports of mineral fuels and lubricants, which decreased to $14.7 \%$. The highest rate of growth in imports [5] was reported for food, beverages and tobacco, with an increase of $49.5 \%$. Imports of these products also increased significantly (up to $33.8 \%$ ), but this increase was overtaken by chemicals and related products, where there was an increase of $34.8 \%$. 


\author{
(online) $=$ ISSN $2285-3642$ \\ ISSN-L = 2285 - 3642 \\ Journal of Economic Development, Environment and People \\ Volume 6, Issue 4, 2017 \\ URL: http://jedep.spiruharet.ro \\ e-mail: office jedep@spiruharet.ro
}



Source: Eurostat (online data code: ext_It_intertrd)

Fig. 2: EU-28 extra trade by main products, EU-28, 2010 and 2015 (EUR billions)

Source: http: //ec.europa.eu/eurostat/statisticsexplained/index.php/International_trade_in_goods/ro

\title{
3. GfK Market Research Institute: The Romanians have spent more and have focused on more expensive products in 2016
}

Year 2016 was another good year for the consumer goods industry, both from retailers and producers, according to a study by GfK. 2016 was the second consecutive year when Romanians had an increased appetite for more expensive products and for higher expenses. The FMCG (Fast Moving Consumer Goods) market grew by $3.4 \%$ compared to 2015 . Behind this growth is a $3 \%$ increase in purchases and up trading (consumer orientation towards products superior in terms of price). Unlike in 2015, up trading was found in both modern and traditional trade. This phenomenon has led to an increase of one percentage point of premium brands at national level, while the other price categories decrease. [7] 


\author{
(online) $=$ ISSN $2285-3642$ \\ ISSN-L = 2285- 3642 \\ Journal of Economic Development, Environment and People \\ Volume 6, Issue 4, 2017 \\ URL: http://jedep.spiruharet.ro \\ e-mail: office jedep@spiruharet.ro
}

Romanians buy less commonly used goods, but spend more on a purchase act. Reducing the shopping frequency was noted exclusively in the fresh food categories, while for home care products the purchasing frequency increased.

Cota de piațä în valoare (\%) [2016]



25 Alimente proaspete (fructe. legume, carne)

Lactate

Alimente ambalate

Bäuturi

Îngrijire personală

İngrijirea locuinței

Altele
Evolutia in valoare $(\%)$ [2016 vs. 2015]

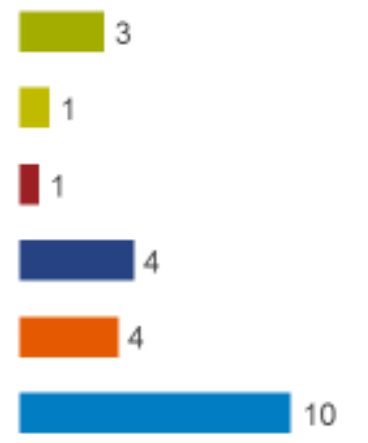

Fig. 3: Two-thirds of spending goes to food

Source: www.retail-fmcg.ro/servicii/studii-de-piata-servicii/studiu-gfk-produse.html

As shown in Figure 3, two-thirds of spending goes to food.

In current consumer goods, food categories still dominate Romanian spending and accounted for $66 \%$.

Household care products, beverages and personal care products had the greatest growth. However, considering the size of the category segments, fresh food and beverages were the ones that contributed most to the growth of the FMCG market. Among the categories that registered increases in 2016 are: seafood and fish, frozen foods, exotic fruits (avocado, pomegranate, etc.), cider, champagne etc.

The hypermarket has become the most important retail channel.

Modern trade covers $57 \%$ of the total FMCG market in Romania. During 2016, modern retailers earned 2 percentage points versus 2015. Supermarket and discount formats contributed most to the growth of modern commerce, gaining a half a percentage point each. The growth of these formats comes from attracting more buyers in stores and increasing the purchasing frequency. Although they had a steady market share in 2016, hypermarkets remain the most important modern channel, accounting for more than a quarter of total home FMCG sales. [7] 


\author{
(online) $=$ ISSN $2285-3642$ \\ ISSN-L = $2285-3642$ \\ Journal of Economic Development, Environment and People \\ Volume 6, Issue 4, 2017 \\ URL: http://jedep.spiruharet.ro \\ e-mail: office jedep@spiruharet.ro
}

Compared to other years, in 2016 retailers' concentration has diminished their growth rate. The market share of the top 10 retailers increased by only 1 percentage point (compared with 3 points in 2015). Among the most active retailers in terms of market share growth are Lidl and Profi. Traditional trade has had a negative evolution during 2016, the decrease of 2 percentage points being determined by a reduction in the frequency of buying from traditional formats by Romanians.

What we expect from 2017

Unlike previous years, 2017 will be characterized by inflation as a result of fiscal relaxation and VAT cuts in 2015 and 2016, which anticipates a slower growth rate.

\title{
4. Shoppers' typology and sales adaptation to entertainment
}

The emergence of "omni" terminology in the retail vocabulary is not up to date, but it is only recently that it is really the focus of attention. The consumer who makes smart choices has suddenly metamorphosed into the omnishopper, that is, the consumer who uses technology learns about the purchasing choices he makes, maximizing his shopping experiences regardless of the environment in which he purchases (physical store or online). This type of consumers is more demanding, social, more connected and more personal-oriented than ever. Those consumers are choosing the store from the retailer's experience, not according to the channel on which the retailer operates. The digital revolution not only gave consumers more comfort, it turned them into more informed consumers and more oriented to save money.

Physical stores have long existed for the growth of sales, and have grown tremendously from the mere act of selling to a sophisticated outrage and investment of hundreds of millions of dollars or euro. Online stores are only 20 years old, but have evolved at a dizzying pace due to the equally spectacular evolution of digital technology.

Marketing activities chosen by the ones interested in doing business include classically testing to identify customer needs, product development, innovative product design to meet existing or latent needs, product promotion to create interest and build brand names, pricing for revenue growth. [2]

Sales activities focus on turning potential customers into buyers if they can even become loyal to them. Sales directly involve interaction with potential customers to convince them to buy the product. Sales techniques are becoming more and more personalized, using digital technology and cyber entertainment methods, in addition to the classic one for keeping the customer as long as possible within the store.

We find out how marketing science tends to focus on the general population, while science sales usually is focused on individuals or small groups of potential customers.

Marketing and publicity specialists have been aware of the limitations of traditional market research methods for decades, but only in recent years the progress of science has allowed the development of a more effective mechanism helping to decipher consumer thoughts: neuromarketing. This name is related with using techniques developed by cognitive neuroscience and psychology specialists to analyze and understand people's reactions to products and promotions, which allows refining marketing efforts to make them more effective. Following brain reactions to different stimuli, researchers can discover the marketing mechanisms that are most likely to lead to the desired outcome: selling the product [1] 


\author{
(online) $=$ ISSN $2285-3642$ \\ ISSN-L = 2285 - 3642 \\ Journal of Economic Development, Environment and People \\ Volume 6, Issue 4, 2017 \\ URL: http://jedep.spiruharet.ro \\ e-mail: office jedep@spiruharet.ro
}

In this battle for profit, innovations determine people, brands, and companies to think about what their true values are. So, all that can be imagined may become real.

It is clear that for most clients, both online and offline are important before an acquisition, and traders know this.

Often, online and physical stores are not in competition, but in many cases they are completing and borrowing features. A great company will try to be strong in both classic retail and online. In malls, more and more sellers work with tablets, store walls are monitors and touch-screens, and users can instantly find out on the Smartphone what discounts they are in the shop they enter, customers can also check the offer on touch screens store on site-like graphics, as proof that the boundaries between online and offline have almost disappeared.

Heads of physical stores know that many of their customers love the internet and technology and will react positively if they meet with them in the store.

On the other hand, online stores try to overcome the huge disadvantage that people can not touch the products and cannot see them live. More and more online stores make video with products, have animations and offer the possibility to analyze the product virtually 360 degrees. On the vast grounds of the mega-mall, you can meet trendy boutiques, supermarkets and grocery stores, entertainment centres, bowling, amusement parks for children, restaurants, food fields, a children's play area, a fitness club with swimming pool and others.

Looking back to the way we purchase products we see that in 2010 , customers start to inform themselves online, but continue to buy offline.

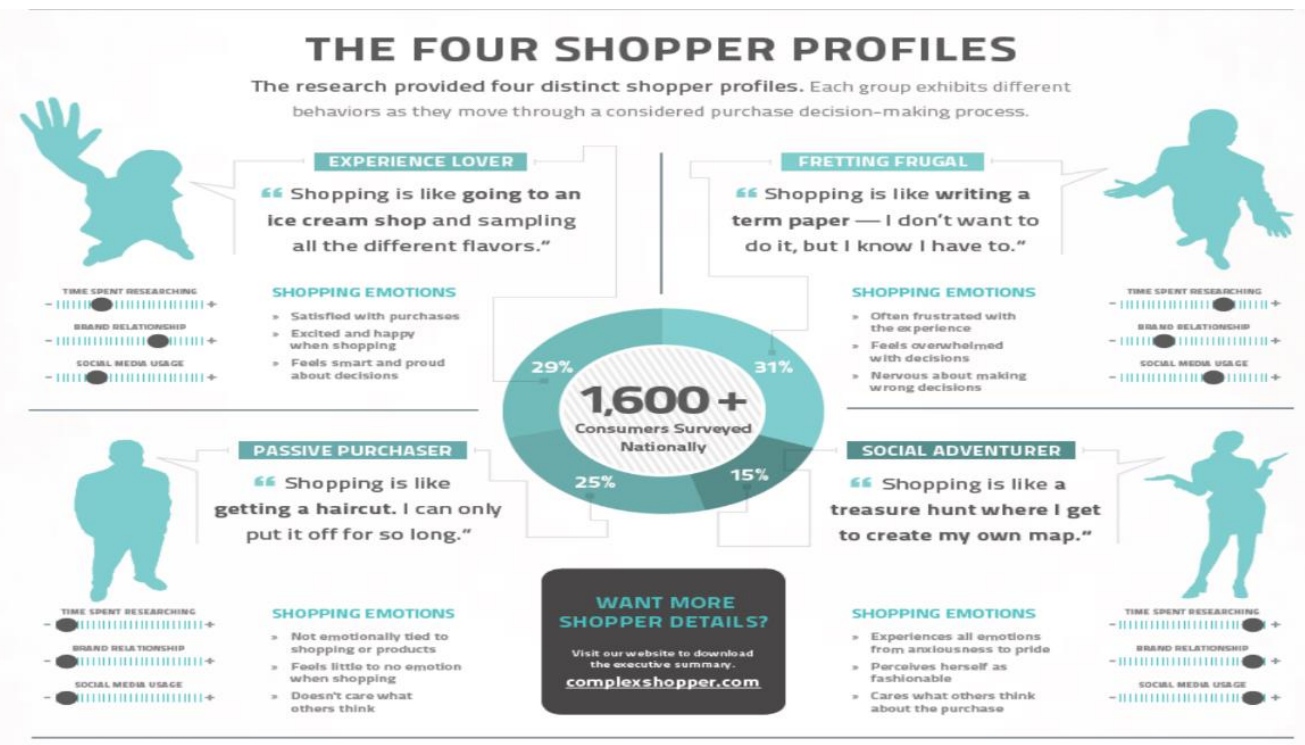

Fig.4. Typology of buyers,

Source: https: //ro.pinterest.com/pin/146437425353750579/

In 2013, Showrooming is invented. People are testing in-store, but they buy online. So far, showrooming is not a strong trend in Romania. You mean bringing in the stores what they like online. 


\author{
(online) $=$ ISSN $2285-3642$ \\ ISSN-L = $2285-3642$ \\ Journal of Economic Development, Environment and People \\ Volume 6, Issue 4, 2017 \\ URL: http://jedep.spiruharet.ro \\ e-mail: office jedep@spiruharet.ro
}

According to Retail Customer Experience, Achieve Global, [6] in 2013-67, 9\% from customers preferred to buy in-store because they could reach and test products; $44.1 \%$ did not want to wait for the delivery of online shopping; 54.3\% thought the offline shopping experience was better than online. [1]

According to a comprehensive study on 1600 shoppers in 2013 (Figure 4), four shopper profiles were outlined:

4.1. The experience lover likes to shop. For $29 \%$ of buyers, shopping is like going to jellyfish and trying all the ice cream flavours. This guy is happy with the choices made, feels proud and smart of the decisions made, and shopping is easier than it seems.

The time spent searching for the product or product information is relatively small, the attachment to the brand is high, the use of social media or online shopping is relatively small.

Want to make SAFARI RETAIL, participate with pleasure in what they DO. DO YOURSELF means and respond to the urge TO GO TO THE PRODUCT!

4.2. The superficial buyer who thinks shopping is like homework. He does not like it, but he knows he has to do it. $31 \%$ of the clients think like this.

The hypothesis of mistaken decisions agitates him. Shopping seems harder than he believed or hoped for. He is usually unhappy with the shopping experience and is the one who complains to the customer service. The time spent searching for the product / product information is relatively high, the attachment to the brand is relatively small, it is well informed in advance because it uses social media and even does online shopping. This type of buyer matches sales personalization through vendor-friendly dialogues, and the reality needs to be enhanced by encouraging slogans. Here, the relationship management with the customer, CRM, is essential.

4.3. The social adventurer who cares about what others think about his decisions is delighted to do research about buying, he likes to enter into dialogue with the company where he bought, is an emotional person, for whom shopping is like a treasure hunt game where you can make your own map. $15 \%$ of shoppers are of this type.

The time spent searching for product / product information, brand attachment, and social media / online shopping have very high values on a scale to measure these attributes. For this type of shopper, it is very important to reward his visit to stores. This means he has to find ways to spend a lot of time at the point of sale. That's how GAMIFICATION appeared, that is, the techniques behind the design of the most effective loyalty program. Common elements of gaming language such as gaming points, badges, leader boards, and levels are proven (and increasingly popular) elements that stimulate and encourage consumer behaviour. The shopper wants to find information quickly on the phone or tablet, being in the store. In his case, offline $=$ online.

4.4. The passive buyer is not interested in the opinion of others, he does not like to do too much research before buying something, when buying something is not emotional, he sees shopping as simple commercial transactions.

For him the shopping is like a haircut. You can take time, and anybody else is doing it anyway. It is represented by $25 \%$ of buyers. 


\author{
(online) $=$ ISSN $2285-3642$ \\ ISSN-L = $2285-3642$ \\ Journal of Economic Development, Environment and People \\ Volume 6, Issue 4, 2017 \\ URL: http://jedep.spiruharet.ro \\ e-mail: office jedep@spiruharet.ro
}

The attributes studied and other consumer typologies have low values, they don't allocate too much time for searching products or necessary information, is not attached to the brand, and uses to a lesser extent social media and online shopping. To attract this type of buyer, you must resort to real artistic performances in the store, exhibitions, even special places for special shoppers equipped with games, TV themed shows etc.

In order to increase sales, we need an efficient promotion of the services offered by companies, and the promotion of brands. Mobile marketing and mobile communication offer this perspective [Catoiu, 2010].

\title{
5. Case Study: Sun Plaza, Bucharest
}

In this mall, it is always intended to give Sun Plaza customers the most enjoyable experiences, which is why weekly the mall is experiencing a new event. Performances and concerts organized within the mall are addressed to both children and adults.

Traditional or holiday festivals, workshops and shows for children, concerts where customers enjoy the most vogue hits of the moment, glamorous sports gaming campaigns or computer games, social projects through which investing in the good of the community, and last but not least, the health and beauty events dedicated to ladies are created from the desire to provide relaxing moments full of good mood and smiles. https://www.sun-plaza.ro/event/da-mai-departe-bucuria-orasul-lui-mos-craciun/

Here is an event organized for 8.12-14.12.2017

"Share the happiness to the City of Santa Claus"

\section{Shop: SUN PLAZA}

Creative workshops, LEGO construction, theatre shows, Santa Claus meetings and carols await you at Sun Plaza. Discover all the surprises we have prepared for you on the 1st floor in the restaurants area between the 8 th and the 24 th of December.

Here's the detailed program:

December 8:

17: 00-18: 00 - Santa's Festive Flea - The Fairytale Parade

18: 00-19: 00 - Christmas Stars - carols recital performed by Bim Bam and Fantezia

December 9:

11: 00-15: 00 - Toys Factory - arts \& crafts workshops and face painting sessions

17: 00-18: 00 - Games Olympics - play and fun

18: 00-19: 00 - Magic Box of Christmas - interactive ice show

December 10:

11:00 - 15:00 - Toys Factory - arts \& crafts workshops and face painting sessions

17: 00-18: 00 - Games Olympics - play and fun

18: 00-19: 00 - The Rolling Strings - musical theatre with puppets 


\author{
(online) = ISSN $2285-3642$ \\ ISSN-L = 2285 - 3642 \\ Journal of Economic Development, Environment and People \\ Volume 6, Issue 4, 2017 \\ URL: http://jedep.spiruharet.ro \\ e-mail: office jedep@spiruharet.ro
}

December 15:

17: 00-18: 00 - Games Olympics - play and fun

18: 00-19: 00 - Christmas Magic Show - an inaugural magic show

December 16:

11: 00-15: 00 - Toys Factory - arts \& crafts workshops and face painting sessions

17: 00-18: 00 - Games Olympics - play and fun

18: 00-19: 00 - Nutcracker - puppet theatre supported by the Musketeers Theatre Company 12:00 - 20:00 - LEGO Workshop - Leo-themed event on the 1st floor, Green Plaza December 17:

11: 00-15: 00 - Toys Factory - arts \& crafts workshops and face painting sessions

17: 00-18: 00 - Games Olympics - play and fun

18: 00-19: 00 - The Winter Stories - reading show

12: 00-20: 00 - LEGO Workshop - Leo-themed event on the 1st floor, Green Plaza

Santa Claus Meeting: 8-23 December

Thursday, Friday 17: 00-19: 00

Saturday, Sunday 13: 00-19: 00

Free gift wrap and free wardrobe corner: 8-24 December

Daily, 12: 00-21: 00, on the 1st floor, Green Plaza

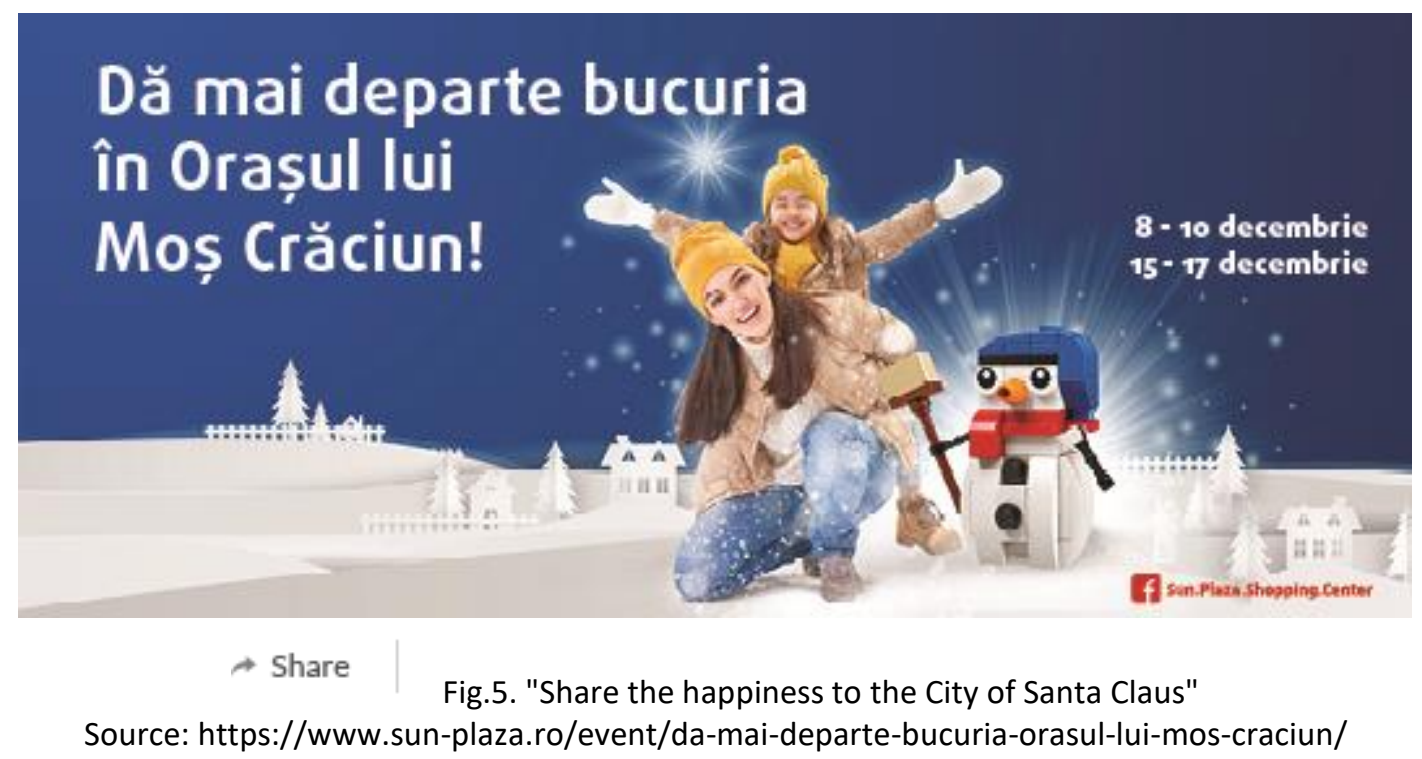




\author{
(online) $=$ ISSN $2285-3642$ \\ ISSN-L = $2285-3642$ \\ Journal of Economic Development, Environment and People \\ Volume 6, Issue 4, 2017 \\ URL: http://jedep.spiruharet.ro \\ e-mail: office jedep@spiruharet.ro
}

\title{
6. Conclusions
}

If retailers have the same prices, the same commodity and are relative to the same consumer distance, they have to find ways to encourage customers to choose their store.

The big chains are heading towards Retailtainment. This new concept adds entertainment or recreation to the retail experience. By combining sales with customer spending, entertainment through sales, it can come back and even recommend that point of sale knowledge. A new concept of Retail + Enterntainment $=$ Retailtainment is reached. Retailtainment does not just mean games, shows inside the store, but a state of well-being and experience that the buyer truly involves.

In the United States, China, the UK, and other technologically advanced countries, the evolution of the retail and entertainment industry is growing at the same pace as the IT industry, generating billions of dollars annually.

"Efficiency" seems to be the operative word when it comes to defining the omnichannel experience that most retailers have adopted in their stores in recent years. Omnichannel is a business model in which the way the interaction between a brand and its consumers / fans is dictated by consumers / fans. The way we buy from a classic store differs from an online store, just as they differ the products we choose to buy. In physical stores we have a sensory relationship with products and we tend to buy under the impulse of the moment, while online we are a little more rational because we can compare and better order the offer.

Brands and smart retailers are already adapting their integrated marketing plans to ensure that all forms of $m$-commerce and e-commerce, online and offline, are a strong point in the acquisition process, and those who do not do it, risks losing a significant market share and failing to attract a new generation of buyers. The store remains the center of gravity for the omnishopper. A destination for the value of entertainment and social interaction, and although value is important, promotions are essential for less than $20 \%$ of the omnishoppers.

We notice the outline of 10 trends that can apply to brands and retailers to increase real sales:

1. PERSONALIZATION in the sale of the product

2. ENHANCED REALITY: Improved reality

3. RETAIL SAFARI - LEISURE EXHIBITIONS

4. EMOTIONS AND DIFFERENT STATIONS

5. PERSONALIZED INFORMATION

6. GESTURG EXPERIENCE

7. GAMIFICATION

8. SHOP IN SHOP

\section{COURSES AND EDUCATION like DO IT YOURSELF}

These sales trends are taking into account the consumer product typologies that they see in shopping and a way of entertainment.

Expert advice refers to adapting experience based on product, retailer, and space available. 


\author{
(online) $=$ ISSN $2285-3642$ \\ ISSN-L = 2285 - 3642 \\ Journal of Economic Development, Environment and People \\ Volume 6, Issue 4, 2017 \\ URL: http://jedep.spiruharet.ro \\ e-mail: office jedep@spiruharet.ro
}

In the example presented in the article, the events scheduled at the mall during the winter holidays bring sales increases and $80 \%$ over the previous month. Concerts, doll or clown shows, fashion parades, raffles, or even automotive contests all turn commercial centers into real-life halls.

Our example shows how to make an ethical, civilized and extremely pleasant commerce when resorting to customer entertainment where the customer no longer pursues the lowest price. He will pay the right price.

\title{
7. References
}

[1] Jelev Viorica, Merchandising, Note de curs,ed. Fundația România de Mâine, 2017

[2] Jelev Viorica, Marketing Internațional, Fundația România de Mâine, 2007

[3] Pistol Gh., Pistol Luminița, Albu Gh., Manea Gelu, Comerțul interior. Teorie și practică, ed.Economica,2004

[4] Shopper culture in http://www.shopperculture.com/the-complex-shopper/

[5] International trade in gooods in http://ec.europa.eu/eurostat/statisticsexplained/index.php/International_trade_in_goods/ro

[6] Loyalty marketing in a Trumpian world in https://www.retailcustomerexperience.com/companies/media/achieveglobal/

[7] Studiu-GFK-produse in http://www.retail-fmcg.ro/servicii/studii-de-piata-servicii/studiu-gfk-produse.html

[8] CĂTOIU, I., GÂRDAN, D., \& GÂRDAN, D. (2010). Mobile marketing future trends. Annals of "Spiru Haret". Economic Series, 10(1), 11-22. Retrieved from http://anale.spiruharet.ro/index.php/economics/article/view/1011 